\section{Experimental study}

Rabbits (2-2.5 kg New Zealand white) were treated with sodium warfarin (daily subcutaneous injection), the dosage being adjusted until the BCR was raised to a steady level (at dose $0.40 \div 0.04 \mathrm{mg}$ ), after which they were also treated with amiodarone chloride solution (Reckitt and Colman) $35 \mathrm{mg}$

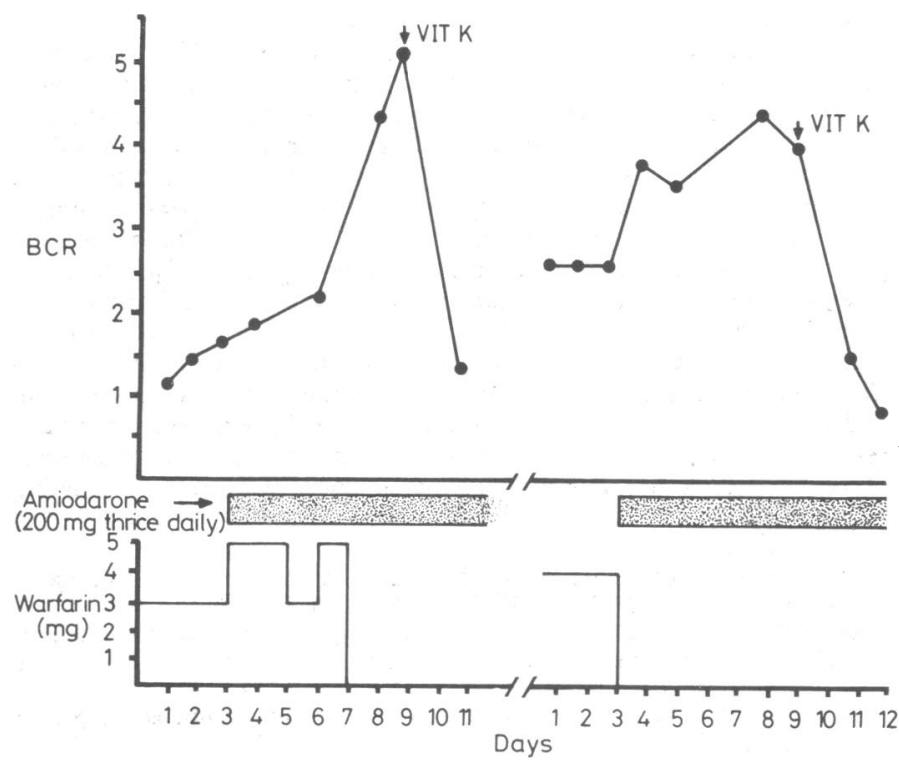

Effect of treatment with amiodarone on British corrected ratio of prothrombin times (BCR).

given in daily subcutaneous injections for four days. Venous blood samples (ear vein) were collected in HEPES-buffered trisodium citrate solution for measurement of prothrombin time, ${ }^{1}$ using both human and rabbit brain thromboplastin (Thromboplastin CAHS (UK) Ltd) and derivation of BCR. Results are given as mean $+S E$ and compared by paired Student's $t$ test. The addition of amiodarone resulted in a significant and striking increase in BCR from a stable level of $2 \cdot 6 \pm 0.38(n=5)$ before amiodarone, to $5.4 \pm 1.4$ on day $1,13.3 \pm 4.0$ on day 2 , and $6.2 \pm 0.59(n=3$, two rabbits having died from gastrointestinal haemorrhage) on day 3 , using human thromboplastin; or from $1.9 \pm 0.21$ to $4.0 \pm 1 \cdot 1,9.1 \pm 3.9$, and $3.6 \pm 0.45$ respectively, using rabbit thromboplastin.

\section{Comment}

Although not yet released for general use in Britain, amiodarone is widely used abroad and under hospital supervision in Britain. It has valuable antiarrhythmic properties ${ }^{2} 3$ associated with prolongation of action potential duration as well as slowing of action potential upstroke and thus conduction velocity. ${ }^{4}$ The need for special care in using amiodarone in combination with anticoagulant drugs has not been recognised. This case report and experimental study clearly indicate the need for great caution in this respect. The Committee for Safety in Medicine has in fact received some reports suggesting such an interaction (personal communication). Amiodarone is highly $(\geqslant 90 \%)$ protein bound in the blood. ${ }^{5} \mathrm{~A}$ possible explanation of the interaction is therefore that it displaces warfarin from protein-binding sites. Alternatively it could influence warfarin metabolism. This has important therapeutic implications for its clinical use in combination with many drugs.

We thank Dr J Giddings, Department of Haematology, University Hospital of Wales, Cardiff, for his help.

Requests for reprints should be addressed to: Professor A H Henderson, Department of Cardiology, Welsh National School of Medicine, Heath Park, Cardiff.

${ }^{1}$ Poller L. The British comparative thromboplastin: the use of the national thromboplastin reagent for uniformity of laboratory control of oral anticoagulation and expression of results. London: Association of Clinical Pathologists, 1970. (Broadsheet 71).

2 Rowland E, Krikler DM. Electrophysiological assessment of amiodarone in the treatment of resistant supraventricular arrhythmias. Br Heart $\mathcal{f}$ $1980 ; 44: 82-90$.

3 Ward DE, Camm AJ, Spurell RHJ. Clinical antiarrhythmic effect of amiodarone in patients with resistant paroxysmal tachycardia. Br Heart $\mathcal{f}$ $1980 ; 44: 91-5$.
${ }^{4}$ Singh BN, Vaughan Williams EM. The effect of amiodarone, a new anti-anginal drug, on cardiac muscle. Br F Pharmacol 1970;39:657.

${ }^{5}$ Charlier R, Deltour G, Bandine A, Chaillet F. Pharmacology of amiodorone. Arzneim Forsch 1968;18:1408-17.

(Accepted 11 March 1981)

Department of Cardiology, Welsh National School of Medicine, Cardiff CF4 4XN

A REES, BSC, $M B$, registrar

J J DALAL, MD, lecturer

P G REID, MB, senior house officer

A H HENDERSON, MB, FRCP, professor

Department of Pharmacology, Welsh National School of Medicine, Cardiff CF4 1XN

$M$ J LEWIS, PHD, MB, lecturer

\section{Emergency treatment of high blood pressure with oral atenolol}

Reduction of blood pressure within two hours with parenteral treatment is necessary in only a few well-defined clinical conditions, such as hypertensive encephalopathy and eclampsia. If pressure is reduced too quickly ischaemia of the heart, brain, or kidneys or blindness may ensue. ${ }^{123} \mathrm{~W}$ ith the exception of these dire emergencies, oral antihypertensive treatment may suffice, but even this may carry some hazard. ${ }^{1}$ We have used a single oral dose of the cardioselective beta-blocker atenolol in very severe hypertension in an attempt to control blood pressure smoothly and avoid rapid falls.

\section{Patients, methods, and results}

Patients with blood pressures exceeding $200 / 130 \mathrm{mg} \mathrm{Hg}$ or with malignant hypertension were treated with $100 \mathrm{mg}$ atenolol by mouth in a single dose. Patients in whom beta-blockers were contraindicated or in whom we suspected a phaeochromocytoma were excluded. Blood pressures were measured by the nursing staff, using standard sphygmomanometers and the fifth phase as diastolic pressure in the resting supine position for at least two hours before and for 12 hours after drug administration. "Pretreatment" blood pressure was taken as that reached when the pressure had stabilised after at least two hours of bed rest.

We studied eight men and two women. All were Caucasians, and their mean age was 46 (range 15-62 years). Nine had malignant hypertension, and only one was receiving treatment. There was a mean fall in pressure of $56 \mathrm{~mm} \mathrm{Hg}$ systolic and $40 \mathrm{~mm} \mathrm{Hg}$ diastolic over 12 hours. No side effects were encountered, and blood-pressure control was achieved smoothly without precipitous drops (table). Nine subjects had normal excretion urograms, serum electrolyte concentrations, and 24-hour urinary output of metanephrines. The remaining patient had evidence of renal artery stenosis on excretion urography.

Reduction of blood pressure in 10 patients after oral atenolol. Figures are means $\pm S D$

\begin{tabular}{lllllll}
\hline & $\begin{array}{c}1 \text { st } \\
\text { baseline } \\
\text { reading }\end{array}$ & 0 & \multicolumn{4}{c}{ Time in hours after dose } \\
\cline { 2 - 7 } & 2 & 4 & 8 & 12
\end{tabular}

Systolic blood pressure $\quad \ldots 230 \pm 14 \quad 224 \pm 17 \quad 214 \pm 14 \quad 200 \pm 21 \quad 193 \pm 25 \quad 176 \pm 22$

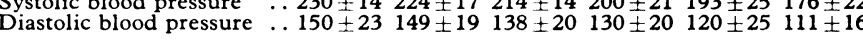

\section{Comment}

Atenolol is rapidly absorbed after oral administration ${ }^{4}$ and is therefore suitable for patients who require rapid reduction of blood pressure. Other studies have shown that labetalol given by mouth is adequate for severe and accelerated hypertension, ${ }^{5}$ and we have found that a beta-blocker alone appears to have an adequate hypotensive effect in malignant hypertension. The prolonged antihypertensive effect of atenolol provides a further advantage in that subsequent doses need not be given for 12-18 hours, though all the present patients subsequently required further drugs to control their blood pressure. Blood pressures after 12 hours were not normal, but a gradual reduction is more important than to achieve this. We 
emphasise that beta-blockade alone can be harmful where a phaeochromocytoma is suspected.

This work was supported by a grant from ICI Pharmaceuticals Ltd.

1 Cove DH, et al. Blindness after treatment of malignant hypertension. Br Med f 1979 ;ii:245-6.

2 Ledingham JGG, Rajagopalan B. Cerebral complications in the treatment of accelerated hypertension. $Q \mathcal{F}$ Med 1979;189:25-41.

3 Watson AJS, Lawlor E, Keogh JAB. Acute folate deficiency during peritoneal dialysis. $\mathrm{Br} \mathrm{Med} \mathcal{F} 1980 ; 281: 1602$.

4 McAinsh J. Clinical pharmacokinetics of atenolol. Postgrad Med $\mathcal{F} 1977$; 53, suppl 3:74-8.

5 Ghose RR, et al. Treatment of hypertensive emergencies with oral labetalol. Br Med f 1978;ii:96.

(Accepted 11 March 1981)

Department of Medicine, Dudley Road Hospital, Birmingham B18 7QH

L T BANNAN, MB, MRCPI, honorary senior research registrar

D G BEEVERS, MD, FRCP, senior lecturer in medicine

\section{Renin-dependent hypertension in polyarteritis nodosa}

Although hypertension and renal disease are common in polyarteritis nodosa, the mechanism of the hypertension is not well understood. Three cases have been described in which hypersecretion of renin appeared to be an important mechanism. ${ }^{12}$ We report a case that has striking similarities with the three others and suggests the possibility of a common underlying pattern.

\section{Case report}

A previously healthy 46-year-old white man developed arthralgia, rash, anorexia, weight loss, mononeuritis multiplex, and hypertension. Investigations showed that he was positive for hepatitis $B$ surface antigen and had hyponatraemia (serum sodium $128 \mathrm{mmol}(\mathrm{mEq}) / \mathrm{l})$, hypokalaemia (serum potassium $2.7 \mathrm{mmol}(\mathrm{mEq}) / \mathrm{l})$, and a creatinine clearance of $70 \mathrm{ml} / \mathrm{min}$. A liver biopsy specimen showed changes of persistent hepatitis.

Plasma renin activity was $20 \mathrm{mmol} / 1 / \mathrm{h}(26 \mathrm{ng} / \mathrm{ml} / \mathrm{h})$, urine sodium excretion $320 \mathrm{mmol} / 24 \mathrm{~h}$, and urine aldosterone excretion $0.2 \mu \mathrm{mol}(71 \mu \mathrm{g}) / 24 \mathrm{~h}$. Because the renin activity was so high renal vein renin activity was measured before and after the administration of captopril $12.5 \mathrm{mg}$, and the results are shown in the table. After administration of captopril blood pressure fell from

Renal vein renin activity (mmol/l/h) before and after captopril

\begin{tabular}{|c|c|c|c|}
\hline & \multicolumn{2}{|c|}{ Renal vein } & \multirow[b]{2}{*}{ Vena cava } \\
\hline & Right & Left & \\
\hline $\begin{array}{l}\text { Before captopril } \\
\text { After captopril }\end{array}$ & $\begin{array}{l}27 \\
97\end{array}$ & $\begin{array}{r}25 \\
114\end{array}$ & $\begin{array}{l}15 \\
68\end{array}$ \\
\hline
\end{tabular}

Conversion: SI to traditional units-renin activity: $1 \mathrm{mmol} / 1 / \mathrm{h} \approx 1 \cdot 3 \mathrm{ng} / \mathrm{ml} / \mathrm{h}$.

$180 / 120$ to $135 / 90 \mathrm{~mm} \mathrm{Hg}$. These results were interpreted as showing bilateral hypersecretion of renin and decreased blood flow (difference between renal vein and vena cava renin activities greater than $25 \%$ ). A renal arteriogram showed normal renal arteries and multiple small aneurysms intrarenally on both sides.

These findings were characteristic of polyarteritis nodosa, and he was treated with cyclophosphamide, propranolol, prazosin, and triamterenehydrochlorthiazide (Dyazide), on which regimen the plasma renin activity fell to $5.8 \mathrm{mmol} / 1 / \mathrm{h}(7.5 \mathrm{ng} / \mathrm{ml} / \mathrm{h})$ and blood pressure to $124 / 78 \mathrm{~mm} \mathrm{Hg}$.

\section{Comment}

The clinical history of this patient strongly suggested renovascular disease as the cause of the sudden onset of severe hypertension, hyponatraemia, and hypokalaemia. Peripheral plasma renin activity was extremely high, at a value normally seen only in patients with malignant hypertension or tight unilateral renal artery stenosis. That the hyperreninaemia was itself responsible for the raised pressure was shown by the dramatic effect of a small dose of captopril in lowering blood pressure.
The suggestion that the hypertension of polyarteritis nodosa might be due to renal ischaemia occurring as a result of vasculitis of the renal arterioles was first made by Dawson et al in $1948,{ }^{3}$ but evidence for this mechanism has so far been lacking. In only one reported case ${ }^{2}$ have renin measurements of the kind reported here been made, and in one other case the blood pressure was responsive to captopril. ${ }^{2}$ A third case, in which the hypertension was shown to be angiotensin dependent by a hypotensive response to saralasin, was reported by Stockigt et al. ${ }^{1}$

The similarity of these four patients is striking. All had typical features of polyarteritis nodosa, with hypertension of recent onset, and were positive for hepatitis B surface antigen, which is normally found in about $30 \%$ of patients with polyarteritis. ${ }^{4}$ The renal findings are particularly interesting. Renal vein renin measurements were performed in three cases, and all showed bilateral hypersecretion of renin, high aldosterone values, and hypokalaemia. Renal arteriography showed bilateral intrarenal aneurysms characteristic of polyarteritis nodosa, but creatinine clearance was surprisingly well preserved, ranging between 70 and $120 \mathrm{ml} / \mathrm{min}$ in the four patients. The renin-angiotensin system was responsible for the hypertension in three of the four cases: in one this was shown by testing with saralasin, and in two with captopril. Since the onset of hypertension has been reported in $20 \%$ of patients with polyarteritis nodosa, ${ }^{5}$ measurements of renin activity are likely to be particularly helpful in evaluating such patients.

1 Stockigt JR, Topliss DJ, Hewett MJ. High-renin hypertension in necrotizing vasculitis. N Engl ₹ Med 1979;300:1218.

2 White RH, Schambelan M. Hypertension, hyperreninemia, and secondary hyperaldosteronism in systemic necrotizing vasculitis. Ann Intern Med 1980;92:199-201.

${ }^{3}$ Dawson J, Ball J, Platt R. The kidney in periarteritis nodosa. $Q \mathcal{F}$ Med $1948 ; 17: 175-202$.

- Sergent JS, Lockshin MD, Christian CL, Gocke DJ. Vasculitis with hepatitis B antigenemia. Medicine 1976;55:1-18.

${ }^{5}$ Rose GA, Spencer H. Polyarteritis nodosa. Qf Med 1957;26:43-79.

(Accepted 4 March 1981)

Cardiovascular Center and Department of Medicine, Cornell University, New York Hospital Medical Center, New York, NY 10021, USA

THOMAS G PICKERING, DPHIL, FRCP, associate professor

MICHAEL D LOCKSHIN, $M D$, associate professor

WILLIAM J EISENMENGER, MD, clinical professor

ARRACH, WILD AND STINKING. Called also Vulvaria, from that part of the body upon which the operation is most; also Dog's Arrach, Goat's Arrach, and Stinking Motherwort.

This has small and almost round leaves, yet a little pointed and without dent or cut, of a dusky mealy colour, growing on the slender stalks and branches that spread on the ground, with small flowers set with the leaves, and small seeds succeeding like the rest, perishing yearly, and rising again with its own sowing. It smells like rotten fish, or something worse.

It grows usually upon dunghills. They flower in June and July, and their seed is ripe quickly after.

Stinking Arrach is used as a remedy to women pained, and almost strangled with the mother, by smelling to it; but inwardly taken there is no better remedy under the moon for that disease. I would o be large in commendation of this herb, were I but eloquent. It is an $D$ herb under the dominion of Venus, and under the sign Scorpio; it is common almost upon every dunghill. The works of God are freely given to man, his medicines are common and cheap, and easily to be found. I commend it for an universal medicine for the womb, and $\mathcal{W}$ such a medicine as will easily, safely, and speedily cure any disease $\sigma$ thereof, as the fits of the mother, dislocation, or falling out thereof; 0 cools the womb being over-heated. And let me tell you this, and I $\frac{\bar{D}}{D}$ will tell you the truth, heat of the womb is one of the greatest causes of hard labour in child-birth. It makes barren women fruitful. It $\square$ cleanseth the womb if it be foul, and strengthens it exceedingly; it $\overline{0}$ provokes the terms if they be stopped, and stops them if they flow $\overrightarrow{\mathbb{D}}$ immoderately; you can desire no good to your womb, but this herb will affect it; therefore if you love children, if you love health, if you $\triangle$ love ease, keep a syrup always by you, made of the juice of this herb, and sugar (or honey, if it be to cleanse the womb), and let such $?$ as be rich keep it for their poor neighbours; and bestow it as freely as I bestow my studies upon them, or else let them look to answer it another day, when the Lord shall come to make inquisition for blood. (Nicholas Culpeper (1616-54) The Complete Herbal, 1850.) 